\title{
Gravity Model in Foreign Trade (Iraqi Dates as a Case Study)
}

\author{
Basim Hazim Al-Badri \\ Dept. of Agricultural Economics, Baghdad University, Baghdad, Iraq
}

Email address:

drbasimbadri@yahoo.com

\section{To cite this article:}

Basim Hazim Al-Badri. Gravity Model in Foreign Trade (Iraqi Dates as a Case Study). International Journal of Applied Agricultural Sciences. Vol. 1, No. 2, 2015, pp. 19-25. doi: 10.11648/j.ijaas.20150102.11

\begin{abstract}
The Gravity Model is considered as one of the important models in foreign trade, because it is used to explain the most important determinants of country exports of it's exported goods and to determine the competitive state for exports of the country in world market, besides it gives an idea about the most important countries in exporting their goods. The study aims to determine the most important factors affecting the flow of Iraqi dates to world market, and to measure the influence of these factors and to determine suitable model to understand most important determinants of foreign trade of Iraqi dates with most important trading partners. The study proved that per capita of GDP, quantity of commodity produced by country ,quantity of commodity exports from Iraq to global market, export price (FOB) of commodity and equilibrium exchange rate of local currency versus US\$, were the most important factors because these factors formed about (\%99) of determinants of flow of Iraqi dates to global market. By analyzing this model with most important trading partners (UAE and Syria), the study found that per capita of GDP representing economic size of the two partners, population in the two partners and the distance between trading capitals with inverse sign were the most important factors. Most of these factors compatible with gravity trade model between states, and these factors determine (\%98) and (\%58) of changes in flow of Iraqi dates to UAE and Syria respectively.
\end{abstract}

Keywords: Gravity, Trading Partners, Foreign Trade, Trading Flow

\section{Introduction}

The evidences of present and the experience of past showed that the markets are inducing economic growth, and limited market is one of main obstacles of development, it is clearly showed that growth and increase in external demand of any products of the country will encourage and direct the investment in it's optimum uses in production and marketing of exporting products, and this would increase the income and then increasingnational saving and investment. The development of agricultural exports of Iraq became especially the most important exported agricultural goods of Iraq :the dates- a target and orientationwhen we achieved it, we insure continuously the development efforts, and then increasing employment chances. The reason of concentration on dates because it is the only agricultural products that exported by Iraq in hardest economical conditions of this country. The quantity product of dates were about $(881,403$ and 676) thousands tons during 1995,2004 and 2013 respectively, and these years represent first, middle and last years of this study, where the Iraqi export values of dates were about (6900,39015 and7435) thousand US\$ forthe same years, while the exported quantities for the same years were (40,160 and22)thousands tons respectively(Ministry of
Planning - years of study). Iraq occupied the ranks (4,6 and 5) during these years within first 20th exporting countries in the world(www.faostat.org). The most important trading partners those imported Iraqi dates were (UAE, Syria, Jordan, Turkey, Egypt, Iran and Morocco) in addition to Iraqi trading partners from Asia and Europe. The studying problem is specified in that although there is a comparative advantage in Iraqi dates which represent an importance part of Iraqi agricultural exports- this comparative advantage was approved by specialized studies- but Iraqi dates exports faced strong competition from some countries those specialized in dates exports, and this was due to the capacity in export and fast progress in agricultural production and exporting, in addition to the shortage of updated information about specifications of exported goods, and this will lead to lose the traditional markets that import Iraqi dates. This study aims to shed light on competitive state of Iraqi exports of dates, in order to achieve the following goals must be achieved:1.Determiningmost important factors affecting the flow of Iraqi dates to world market, and measure influence of these factors.2. Determining the suitable model to understand most important determinants of foreign trade of Iraqi dates with most important trading partners. This study will depend upon (Gravity Trade Model) or as named also (Flow of Trade 
Model), as it based on a theoretical base, and agreed with modern studies which trying to explain foreign trade and its flow, besides it takes into consideration largest number of explained variables of foreign trade between countries. This model is used to identify main factors that affecting Iraqi dates exports to most important external markets. This model can be specified as follows[1]:

$$
F i j=f(\text { GDPi, PRODi, QEXij, Pij, EERi) }
$$

Where:

Fij= Value of commodity export from country (i) to world market (j) in US\$.

GDPi $=$ Per capita of GDP of country (i) in US\$.

PRODi= Quantity of commodity production in country (i).

QEXij= Quantity of commodity export from country (i) to world market (j) in ton.

Pij= The export price of commodity from country (i) to world market (j).

EERi=Equilibrium exchange rate of local currency of country (i)in US\$.

The other formula of model which determine most important variables those affecting the flow of Iraqi dates to most important trading partners is:

$$
\begin{aligned}
\operatorname{LnTij}= & \beta o+\beta 1 L n Y i+\beta 2 L n N i+\beta 3 L n Y j+\beta 4 L n N j- \\
& \beta 5 L n D i j+\beta 6 L P i j+\beta 7 \text { Borij }
\end{aligned}
$$

Where:

Tij= Value of exports in US\$ from country (i) to country (j) in the same year.

$\mathrm{Yi}, \mathrm{Yj}=$ Per capita of GDP in both countries (i) and (j) respectively in US\$ for the same year.

$\mathrm{Ni}, \mathrm{Nj}=$ Population in both countries (i) and (j) respectively.

$\mathrm{Dij}=$ The distance in kilometer between both economic capitals of (i) and (j).

$\mathrm{Pij}=$ The export price of commodity from country (i) toimporter country (j).

Borij = Dummy variable equaled (1) if the trade had done between two countries sharing in borders, otherwise it is equal (zero).

The study depends on secondary data obtained from data base of Food and Agriculture Organization (FAO), United Nations (UN), World Bank and the Central Statistical Organization/ Ministry of Planning in Iraq. The Importance of study comes from importance of dates, as the most important exported agricultural products in Iraq, for supporting trade balance of Iraq by creating fixed export markets all over the world, and this will support the ability of Iraqi economy to override unilateral nature which suffers from it, especially Iraq gets the first place among the first $20^{\text {th }}$ exporters in the world for years 2008, 2009 and 2010 depending on quantities of dates. The study hypothesized thatto determine and to measure the most important factors those affecting on trade and flow of Iraqi dates to its most important trading partners, competitive countries and global market have very important influence on the ability of facing competitiveness that Iraqi dates facing, and to determine most important countries those are competitive with Iraq in world export markets of dates.

\section{Main Body (the Model)}

\subsection{The Trade Gravity Model (Analytical Trade Flow)}

The Trade Gravity Model depends on the base of physical equation (Newton equation) about gravity that its substance is (The size of trade between two countries is directly proportional with economy of the two countries and inversely with the distance between them).The basic model of trading gravity could be explained as follows:

$$
F_{i j}=\frac{M_{i}^{a} M_{j}^{b}}{D_{i j}^{y}}
$$

Where: Fij= Value of export flow from country (i) to country (j).

$\mathrm{MiMj}=$ Economical size of two countries expressed as (GDP).

Dij= The distance between two countries measured by distance between two capitals.

By taking natural logarithm of former model can obtain the linear relation between logarithm of trade flow and logarithm of economic size and distance as follows:

$$
\operatorname{Ln} \mathrm{Fij}_{\mathrm{ij}}=\alpha_{\mathrm{o}}+\alpha \operatorname{Ln} \mathrm{Mi}+\beta \operatorname{Ln} \mathrm{Mj}_{j}-\mathrm{y} \operatorname{Ln} \mathrm{Dij}_{\mathrm{ij}}+\varepsilon \mathrm{ij}
$$

$\varepsilon \mathrm{ij}=$ error limit

This makes it clear that the basis in the model of Trading Gravity (The Flow of Trade) is that it is supposed to do trade between two countries depends on the increase in their volume measured by the overall domestic incomes or gross domestic product (GDP) for two countries, and the decline in transportation costs which are measured by the distance between two economic centers (economic capitals) of the two countries[2]:

\subsection{The Modified Trade Gravity Model}

The first economist who added set of variables in Trade Gravity model was (Linnemann) in 1966, where he introduced the population variable as an indicator to the economic size of country, thus was obtained the (Modified Trade Gravity Model), and results indicated ability to addition more variables such as per capita income as an indicator of economic growth level of country, exchange rate and dummy variables such as common language betweenthe two countries and trade agreements between them, therefore the gravity model gives high strength estimators, and this makes the commodity suitable depending on what are obtained from data[3].Anderson is considered as the first economist who modified the general framework, in 1979 by adding the assumption of (Armigton) which states that various countries can produce various commodities and exchange these commodities in imperfect randomly form. The formula of gravity model assumed (Cobb - Douglas Spending System) in monopolistic competition, and each 
country assumed to specialize in one commodity, and have similar tastes, therefore the trading flow from country (i) to country $(j)$ is Fij in period $(t)$ can showas follows[4]:

$$
\mathrm{Fij}=\theta \mathrm{iMj}
$$

Or

$$
\theta \mathrm{i}=\frac{F i j}{M j}
$$

whereas:

$\theta \mathrm{i}=$ Expending income on products of country (i) with assumption of its application on all importers .

$\mathrm{Mj}=$ GDP in imported country $(\mathrm{j})$.

And because the production in country (i) = consumption + exports of commodities, thus GDP of country (i)is calculated as follows[5]:

$$
\mathrm{Mj}=\sum \mathrm{Fij}=\sum \theta \mathrm{iMj}=\theta \mathrm{i}\left(\sum \mathrm{Mj}\right)
$$

Or

$$
\frac{\theta \mathrm{i}}{\mathrm{Mw}}=\frac{M i}{\sum \mathrm{Mj}}=\mathrm{Mi}
$$

Where:

$\mathrm{Mw}=\sum \mathrm{Mj}$ is the global GDP which is considered fixed in each country pairs.

From equation (1) and (2), can deduce equation (3) as follows:

$$
\sum F \mathrm{ij}=\frac{M i M j}{M w}=\frac{(T i j)(M i M j)}{\sum \mathrm{Mj}}
$$

where:

Tij= Value of constant variable (which is not varied during the time like distance).

$\mathrm{W}=$ The countries of the world[6].And from this can find that gravity model equation depends on the addition of the constraints of Cobb - Douglas Spending System with Identical Homothetic Preference [7].

\subsection{Basic Equation of Trade Gravity Model}

By adding natural logarithm to each side of equation (3), basic equation of Trade Gravity Modelcan be obtained:

$$
\mathrm{Ln} F \mathrm{Fij}=\alpha+\beta \mathrm{LnMi}+\mathrm{yMj}+\theta \mathrm{LnTij}
$$

Whereas:

$$
\mathrm{LnMw}=\alpha .
$$

Due to thefact that countries do not have a symmetry homogeneity oftastes, therefore the equations cannot be consolidated, but this does not mean difference in their signs in the same trading level that agreed with, because the trade gravity model supported results of estimations those are reached because of difference in nature of commercial relations among countries, and this belongs to difference in cultural, historical, political and geographical factors those explain in the same time the size of bilateral trade between two countries[8].Although of difficulty of notice those factors and quantitative estimation of them, they had had the possibility of control in these factors depending on what is known as(Country Pair Fixed Effects) in equation of trade gravity model to determine these unnoticed differences, and the trade gravity model equation became as follows:

$$
\mathrm{LnFij}=\alpha 0+\alpha i j+\alpha \operatorname{LnMi}+\beta \operatorname{LnMj}-y \operatorname{LnDij}+\varepsilon i j
$$

And this may contradict with two parts:

The first one is joint with all countries those dealing with each other $(\alpha 0)$

The other one is allocated for two exclusive countries

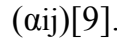

\subsection{Formulation and Variables of Model}

This study will analyze two models of trading gravity about Iraqi dates, the first one about trading flow of Iraqi dates and measuring the most important determinants of this flow, by using gravity model in this formula:

$$
\begin{array}{r}
\mathrm{LnFij}=\beta \mathrm{o}+\beta 1 \mathrm{LnGDPi}+\beta 2 \mathrm{LnPRODi}+\beta 3 \mathrm{LnQUANij}+\beta 4 \mathrm{LnPij} \\
+\beta 5 \mathrm{LnRTi}
\end{array}
$$

Fij= Value of commodity exports from country (i) to global market (j) in US\$ (Y).

GDPi=Per capita of GDP in US\$ in country (i) (X1).

PRODi=Quantity of commodity produced by country (i) (X2).

QUANij=Quantity of commodity exports from country (i) to global market (j) in ton (X3).

$\mathrm{Pij}=$ Export price (FOB) of commodity from country (i) to global market (j) (X4).

$\mathrm{RT} i=$ Equilibrium exchange rate of local currency of country (i) versus US\$ (X5).

The second model is about flow of Iraqi dates with UAE (United Arab Emirates) as being a competitive country in production and exporting dates, where it exports dates and at the same time imports Iraqi dates, and this analysis will be repeated for exports of Iraqi dates to Syria where it is noncompetitive country because it is non-exporting the dates and at the same time imports Iraqi dates, and we'll see where the influence of per capita of GDP and population in each exporter and importer country, and also analyzes the influence of geographical distance by using gravity model in the following mathematical formula:

$$
\begin{array}{r}
\operatorname{LnTij}=\beta o+\beta 1 \mathrm{LnYi}+\beta 2 \mathrm{LnNi}+\beta 3 \mathrm{LnYj}+\beta 4 \mathrm{LnNj}+\beta 5 \mathrm{LnPi}+\beta 6 \mathrm{Ln} \\
\qquad \mathrm{Pj}-\beta 7 \mathrm{LnDij}+\beta 8 \text { Borij }
\end{array}
$$

Whereas:

$\mathrm{Tij}=$ Value of exports in US\$ from country (i) to country (j) in the same year $(Y)$.

$\mathrm{Yi}, \mathrm{Yj}=$ GDP in both countries (i) and (j) respectively valuedby US\$ in the same year.

$\mathrm{Ni}, \mathrm{Nj}=$ Population in both countries (i) and (j) respectively.

$\mathrm{PiPj}=$ Per capita of GDP in both countries (i) and (j) respectively valuedby US\$ in the same year.

Dij= The distance in kilometer between both capitals of (i) 
and $(\mathrm{j})$.

Borij= Dummy variable equals (1) if the trade is between two countries sharing in borders, otherwise it equals (zero).

The study has been chosen UAE and Syria because the fact that these two states are consideredmost important trading partners with Iraq in dates trade.

\section{Results and Discussion}

Appendices (1) and (2), show all parameters of model variables in Iraq and its trading partners (UAE and Syria)with Iraqi exports from dates to trading partners in US\$ which are, per capita of GDP of Iraq and its two trading partners in US\$ and number of population in Iraq and its two trading partners, knowing that distance in kilometer between Baghdad and Abu Dhabi about (1396.6) kilometer, and between Baghdad and Damascus about (717.6) kilometer. By analyzing data in appendix (1) using panel data and by using statistical program (SPSS) via Ordinary Least Squares (OLS) to single equations about the trading flow of Iraqi dates, and measuring the most important determinants of this flow, can obtain the following equation:

$$
\begin{gathered}
\mathrm{LnFij}=1.843+0.318 \mathrm{LnX} 1+0.368 \mathrm{LnX} 2+1.042 \mathrm{LnX} 3- \\
0.187 \mathrm{LnX} 4-0.023 \mathrm{LnX} 5 \\
(\mathrm{t})(1.419)(5.435)(2.594)(28.065)(-0.817)(-0.958) \\
R=0.992, R^{2}=0.987, R^{2 \prime}=0.981 \mathrm{~F}=190.455 \mathrm{D}-\mathrm{W}=1.730
\end{gathered}
$$

The model is significant atlevel (1\%).

The model shows very strong positive relation (0.99) between (1) the value of Iraqi dates exports,(2) quantity of each of the production and (3) exports from dates, while the relation was inverse between the value of Iraqi dates exports and each of the border price of dates (FOB) and exchange rate of Iraqi dinar versus US\$, and this is natural situation. From the model, we can see the significant relation between the value of Iraqi dates exports and each of the quantity of the production, and exports and per capita of GDP, while the relation was insignificant between the value of Iraqi dates exports and each of the (FOB) price and exchange rate. The mathematical model which estimates the relation between the value of Iraqi dates exports and each of the quantity of the exports, export price, per capita of GDP, exchange rate and the quantity of the production was significant overall, because value of (F- ratio) at level (0.01) was (190.455), and the $\left(R^{2}=0.987\right)$, and this indicates that the variables in study explained more than $(98 \%)$ of the change in the value of Iraqi dates exports. Because the model was logarithmic, therefore parameters of model (b's) represent elasticities of the trading flow. The elasticity of the trading flow (b1) was (0.318), and it is the elasticity of income, and this means that trading flow of Iraqi dates will increase by $(0.318 \%)$ when per capita of GDP increases by (1\%), and the trading flow will increase about $(0.368 \%)$ and $(1.042 \%)$ when the produced and exported quantity of dates increase by $(1 \%)$, and the elasticity of the trading flow regarding that exported quantity of dates was high, while the trading flow of Iraqi dates increases by $(0.187 \%)$ and $(0.023 \%)$ respectivelywhen the FOB price of dates and exchange rate of Iraqi Dinar versus US\$ decreases by $(1 \%)$, because the negative sign of these parameters, and price elasticity was $(-0.187)$, and both of income and price elasticity were compatible with economic logic. The second model is about flow of Iraqi dates with UAE as being a competitive state in production and exporting dates, where it exports dates and at the same time imports Iraqi dates and it is an important partner to Iraq in foreign trade of dates, while the third model is about flow of Iraqi dates with Syria where it is non-competitive country because it is not-exporting the dates and at the same time important partner of Iraq, and this was estimated by (2SLS), as in the following equations:

$$
\begin{array}{rl}
\text { LnTij }=872369 & 47+5026 \operatorname{Ln} Y-1110800.37 \operatorname{Ln} Y 2 \\
& +128626.69 \operatorname{LnN} 1-112957.60 \operatorname{LnN} 2 \\
& +27150.34 \operatorname{LnP} 1-56078.36 \operatorname{LnP} 2 \\
& -5123.34 \operatorname{Ln} D i j+2378.1 \text { Borij }
\end{array}
$$

$$
\begin{aligned}
& t(1.00)(2.42)(-3.88) \\
& (2.18)(-4.18)(2.78) \\
& (-2.14)(-2.11)(3.29) \\
& \quad R^{2}=0.93, R^{2 \prime}=0.90, \mathrm{~F}=240.580 \mathrm{D}-\mathrm{W}=1.93 \mathrm{~S} \mathrm{e}=9349.92
\end{aligned}
$$

The parameters of model (b1) and (b7) are elasticities of trading flows to interpret levels of states economic sizes and distance between them. The trading flow increases by (b1\%), when the economic size of state (i) increase by $(1 \%)$, while the trade between two states ( $i$ and $j$ ) decreases when the distance between them increases by (1\%).From this model, it seems that all parameters were compatible with economic logic-except b2\& b4-especially an economic size of state and distance between states, the parameter of economic size of state expressed by GDP (b1) and (b2) were significant at level (1\%),and parameter of population number (b3) and (b4) were significant also at the same level, also the parameters of both of per capita of GDP (b5\& b6) and distance (b7) and dummy variable (b8) are also significant at the same level, but parameters (b6 and b7) were significant at level (5\%) . The significance of model overall was very high at level (1\%) according to $\mathrm{F}$ - ratio. The model does not suffer from Autocorrelation, and by using (2SLS) the model override Multicollniarity, besides that this problem can be override in Macro models of this study[10]. The explaining power of the model was very high because the coefficient of determination $\left(R^{2}\right)$ was $(93 \%)$, and that means all changes in trading flow of Iraqi dates to its more important trading partners (UAE) belongs to independent variables those included in the model. The income elasticity was (5.026), which is compatible with logic of economic theory. The model was logarithmic, therefore the parameters of (b's) represent elasticitis of trading flow, the elasticity of trading flow relating to (b1) was (5.26) and it represents income elasticity. 
The third model is about flow of Iraqi dates with Syria where it is non-competitive country because it is nonexporting the dates and at the same time important partner with Iraq, and this was estimated by (2SLS), as in the following equations:

$$
\begin{aligned}
\operatorname{LnTij}=11.57+ & 3.61 \operatorname{Ln} Y 1+7.34 \operatorname{Ln} Y 2-26.01 \operatorname{LnN} 1 \\
& +28.20 \operatorname{LnN} 2-3.62 \operatorname{Ln} P 1+1.68 \operatorname{Ln} P 2 \\
& -0.10 \operatorname{LnDij}-2.02 \text { Borij }
\end{aligned}
$$$$
t \quad(0.87)(2.99)(3.45)(-1.73)
$$$$
(1.83)(-1.75)(1.83)(-0.40)
$$$$
(-1.98)
$$

$$
\mathrm{R}=0.58, R^{2}=0.49, R^{2 \prime}=0.41 \mathrm{~F}=3 . \mathrm{D}-\mathrm{W}=1.85 \mathrm{Se}=0.84192
$$

The parameters of model (b1) and (b7) are elasticities of trading flow to interpret levels of states economic sizes and distance between them. The trading flow increase by (b1\%), when the economic size of state (i) increases by (1\%), while the trade between two states ( $i$ and $j$ ) decrease when the distance between them increase by $(\% 1)$. From this model, it seems that all parameters were compatible with economic logic except (b3\& b7), the parameter of economic size of state expressed by per capita of GDP (b1) and (b2)were significant at level (5\%), and parameter of population number (b3) and (b4) were insignificant, also the parameter of distance (b7) was insignificant, and dummy variable parameter (b8)

The significant of model overall was very low according to F- ratio at level $(10 \%)$. The model does not suffer from Autocorrelation, and by using (2SLS) the model override Multicollniarity, besides this problem can be override in Macro model as the models of this study. The explaining power of the model was low because the coefficient of determination $\left(R^{2}\right)$ was $(\% 49)$, and that's means not all changes in trading flow of Iraqi dates to its more important trading partner (Syria) belongs to independent variables those included in the model. The income elasticity was $(0.361)$, and compatible with logic of economic theory. The model was logarithmic, therefore the parameters of (b's) represent elasticitis of trading flow.

\section{Conclusions}

1- Per capita of GDP, quantity of commodity produced by country, quantity of commodity exports from country to global market, export price (FOB) of commodity to global market and equilibrium exchange rate of local currency of country versus US\$ were the most important determinants of flow of Iraqi dates to global market .

2- The most important determinants of foreign trade of Iraqi dates with its most important trading partners (UAE and Syria)are GDP and per capita of GDP which represent economic size of Iraq and two partners, population in Iraq and two partners and the distance between trading capitals with inverse sign, and most of their parameters are compatible with the trade gravity model.

3-Elasticites of trading flow are compatible with logic of economic theory in the models especially in model of Iraqi trade to global market, the income elasticity was $(0.318)$ and the price elasticity was $(-0.187)$.

4-The decrease in exchange rate of Iraqi dinar versus US\$ caused an increase in the flow of Iraqi dates exports to trading partners, and if the trading partner has common border with Iraq this will increase the flow of Iraqi dates exports to it.

\section{Acknowledgments}

I would like to thank Prof. Dr. Abdallah A. Mudhi. His

\begin{tabular}{|c|c|c|c|c|c|c|}
\hline year & $\begin{array}{l}\text { Value of Iraqi dates } \\
\text { exports }(1000 \$)\end{array}$ & $\begin{array}{l}\text { Per capita of GDP } \\
\text { (\$)In Iraq }\end{array}$ & $\begin{array}{l}\text { Production } \\
\text { quantity of Iraqi } \\
\text { dates (1000 ton) } \\
\end{array}$ & $\begin{array}{l}\text { Quantity of exporting } \\
\text { Iraqi dates (1000 ton) }\end{array}$ & $\begin{array}{l}\text { FOB price of Iraqi } \\
\text { dates to global } \\
\text { market (\$/ton) }\end{array}$ & $\begin{array}{l}\text { Equilibrium exchange rate } \\
\text { of I.D versus } \\
\text { US\$ }\end{array}$ \\
\hline 1995 & 6900.00 & 171 & 881.0 & 40.00 & 172.5 & 1.674 \\
\hline 1996 & 8500.00 & 290 & 797.4 & 50.00 & 170.0 & 1170 \\
\hline 1997 & 16000.00 & 307 & 750.1 & 90.00 & 177.7 & 1470 \\
\hline 1998 & 20000.00 & 380 & 913.0 & 100.00 & 200.0 & 1620 \\
\hline 1999 & 5000.00 & 642 & 763.7 & 30.00 & 166.6 & 1972 \\
\hline 2000 & 71361.62 & 710 & 931.5 & 291.02 & 245.2 & 1938 \\
\hline 2001 & 75645.21 & 721 & 906.0 & 292.10 & 258.9 & 1929 \\
\hline 2002 & 76611.49 & 691 & 912.0 & 340.08 & 225.2 & 1957 \\
\hline 2003 & 993.00 & 637 & 790.0 & 5.01 & 198.2 & 1936 \\
\hline 2004 & 39014.33 & 982 & 402.8 & 164.35 & 237.3 & 1452 \\
\hline 2006 & 48326.00 & 1944 & 432.1 & 204.03 & 236.8 & 1475 \\
\hline
\end{tabular}
encouragement has been invaluable.

\section{Appendices}

Appendix 1. variables of trading flow model (gravity) of Iraqi dates during the period 1995 - 2013. 


\begin{tabular}{lllllll}
\hline year & $\begin{array}{l}\text { Value of Iraqi dates } \\
\text { exports (1000\$) }\end{array}$ & $\begin{array}{l}\text { Per capita of GDP } \\
\text { (\$)In Iraq }\end{array}$ & $\begin{array}{l}\text { Production } \\
\text { quantity of Iraqi } \\
\text { dates (1000 ton) }\end{array}$ & $\begin{array}{l}\text { Quantity of exporting } \\
\text { Iraqi dates (1000 ton) }\end{array}$ & $\begin{array}{l}\text { FOB price of Iraqi } \\
\text { dates to global } \\
\text { market (\$/ton) }\end{array}$ & $\begin{array}{l}\text { Equilibrium exchange rate } \\
\text { of I.D versus } \\
\text { US\$ }\end{array}$ \\
\hline 2007 & 39674.88 & 2606 & 425.4 & 170.49 & 232.7 & 1267 \\
2008 & 28794.32 & 3622 & 476.1 & 119.13 & 241.7 & 1203 \\
2009 & 11897.15 & 3772 & 516.7 & 40.38 & 294.6 & 1182 \\
2010 & 13755.88 & 3942 & 566.5 & 42.44 & 324.1 & 1186 \\
2011 & 15152.86 & 4251 & 618.9 & 47.00 & 322.4 & 1170 \\
2012 & 25075.13 & 4557 & 655.1 & 50.00 & 176.8 & 1170 \\
2013 & 33750.00 & 6534 & 676.1 & 90.00 & 375.0 & 1170 \\
\hline
\end{tabular}

\section{Source:+}

1.Ministry of Planning, Statistical Central Organization, The study years, National Accounts Directorate, Agricultural Statistics Directorate \& Trade Statistics Directorate, Baghdad.

2. www.un.comtrade.org, The years of study.

Appendix 2. variables of trading flow model (gravity) for Iraqi dates to its most important trading partners (UAE and Syria) through the period 1995 - 2013.

\begin{tabular}{|c|c|c|c|c|c|c|c|c|}
\hline \multicolumn{5}{|l|}{ Syria } & \multicolumn{4}{|l|}{ UAE } \\
\hline Year & $\begin{array}{l}\text { GDP } \\
(1000000 \$)\end{array}$ & $\begin{array}{l}\text { Value of ofraqi Iraqi } \\
\text { datestoto } \\
(1000 \$)\end{array}$ & $\begin{array}{l}\text { Population } \\
\text { (1000) }\end{array}$ & $\begin{array}{l}\text { Per capita } \\
\text { of GDP } \\
(\$)\end{array}$ & $\begin{array}{l}\text { GDP } \\
(1000000 \$)\end{array}$ & $\begin{array}{l}\text { Value of raqi } \\
\text { Iraqi datest } \\
\text { toUAE }(1000 \$)\end{array}$ & $\begin{array}{l}\text { Population } \\
(\mathbf{1 0 0 0})\end{array}$ & $\begin{array}{l}\text { Per capita } \\
\text { of GDP } \\
(\$) \\
\end{array}$ \\
\hline 1995 & 13546.72 & 912.0 & 14338 & 943 & 65743.61 & 6984.0 & 2346 & 28020 \\
\hline 1996 & 15149.38 & 1555.0 & 14746 & 1026 & 73571.22 & 48119.0 & 2470 & 29776 \\
\hline 1997 & 16182.77 & 1621.0 & 15168 & 1066 & 78836.2 & 49434.0 & 2608 & 30217 \\
\hline 1998 & 17468.37 & 10204.0 & 15591 & 1120 & 75674.39 & 73582.0 & 2753 & 27483 \\
\hline 1999 & 17806.34 & 7892.0 & 15996 & 1113 & 84445.4 & 92175.0 & 2893 & 29183 \\
\hline 2000 & 19665.71 & 8014.0 & 16371 & 1201 & 104337.47 & 59975.0 & 3026 & 34476 \\
\hline 2001 & 21008.32 & 7054.0 & 16701 & 1253 & 103311.64 & 71189.0 & 3132 & 32985 \\
\hline 2002 & 21782.04 & 890.0 & 16995 & 1282 & 109816.20 & 55189.0 & 3223 & 34062 \\
\hline 2003 & 20857.55 & 2765.0 & 17298 & 1206 & 124346.35 & 41717.0 & 3369 & 36906 \\
\hline 2004 & 24545.80 & 3008.0 & 17676 & 1389 & 147824.24 & 34036.0 & 3658 & 40404 \\
\hline 2005 & 20396.99 & 9521.0 & 18167 & 1363 & 180617.46 & 28541.0 & 4148 & 43534 \\
\hline 2006 & 33108.81 & 8508.0 & 18805 & 1761 & 222116.53 & 29713.0 & 4875 & 45556 \\
\hline 2007 & 40271.78 & 2386.0 & 19561 & 2059 & 257916.19 & 393.0 & 5797 & 44489 \\
\hline 2008 & 52557.91 & 819.0 & 20346 & 2583 & 315474.61 & 9822.0 & 6798 & 46403 \\
\hline 2009 & 54111.73 & 5408.0 & 21031 & 2573 & 253547.44 & 7650.0 & 7718 & 53013 \\
\hline 2010 & 60465.12 & 6356.0 & 21533 & 2808 & 286049.28 & 8656.0 & 8441 & 34409 \\
\hline 2011 & 53678.20 & 7799.0 & 21804 & 2948 & 347454.06 & 7122.0 & 8925 & 39058 \\
\hline 2012 & 41499.94 & 3928.0 & 22110 & 2126 & 372313.95 & 6787.0 & 9205 & 41692 \\
\hline 2013 & 35164.40 & 3425.0 & 22300 & 2314 & 406583.79 & 8112.0 & 9645 & 48992 \\
\hline
\end{tabular}

\section{Source:+}

www.un.comtrade.org-The study years.

\section{References}

[1] R. Amin, Z. Hamid and N. Saad, "Does Trade Among ASEAN Members Promote Efficiency? Sectorial Evidence from the Gravity Model", International Journal of Humanities and Social Science, Vol. 1,p.p 237- 243,2011.

[2] E. Tafenan, "Explaining German Imports of Olive Oil Evidence from Gravity Model", Paper prepared from presentation at the 12th congers people, Food and Environment, Global Trends and European- Strategies- Gent, Belgium,p.p.23-26.2009.

[3] H. Sandberg, "Caricom Bilateral Trade: A preliminary analysis using the gravity model", Technical Paper series by international of agricultural trade and policy center, p.p. 6269,2002 .

[4] H. El- Nader, A. El- Raimony, \& A. Irshaidat, "An Empirical Study of the Determinants of Tourism Exports Flow: Using Gravity Model, the Case of Jordan (1976-2005)", El- Yarmok Researches Journal, Erbid, Vol. 26, p.p. 761-782, 2010.

[5] S. Santos, and T. Silvana, "The log of Gravity", The Review of Economics and Statistics, 88(4) , p.p.641-645,2006.

[6] A. Al- Edary, \& M. Al-Shamarie, "Estimate The Gravity Model Of United States Of America And Some Countries For The Period From 1991-2011/ an Econometric Study", International Journal of Humanities and Social Sciences (IJHSS), Vol. 3, p.p.101-116,2014. 
[7] J. Johnson, "Determinants of Wheat Trade 1999 - 2008", Master thesis, Department of Agricultural Economics, College of Agriculture, Kansas State University, Manhattan,p.p.113120,2011 .

[8] T. Chaney, "The Gravity Equation in International Trade: An Explanation", University of Chicago, NBER and CEPR. p.29,2011 .
[9] H. Hassanin, "Gravity Trade Model: Application on Rice and Orange", Master Dissertation, Dept. of Agricultural Economics, College of Agriculture, Zagazig University, p. p.34-39,2010.

[10] P. Egger, "An econometric view on the estimation of gravity models and the calculation of trade potentials", World Economy J., vol.25, pp.297-312,2002. 